\title{
Surfaces
}

\section{Some Notes on "culture", "Humanism", and the "Humanities" in Modern Chinese Cultural Discourses}

\section{Leo Ou-fan Lee}

Volume 5, 1995

\section{DEUXIÈME CONGRÈS INTERNATIONAL SUR LE DISCOURS HUMANISTE (1995)}

SECOND INTERNATIONAL CONFERENCE ON HUMANISTIC DISCOURSE (1995)

URI : https://id.erudit.org/iderudit/1065002ar

DOI : https://doi.org/10.7202/1065002ar

Aller au sommaire du numéro

Éditeur(s)

Les Presses de l’Université de Montréal

ISSN

1188-2492 (imprimé)

1200-5320 (numérique)

Découvrir la revue

Citer cet article

Lee, L. O. (1995). Some Notes on "culture", "Humanism", and the "Humanities" in Modern Chinese Cultural Discourses. Surfaces, 5.

https://doi.org/10.7202/1065002ar
Résumé de l'article

Cet essai est une réponse aux questions soulevées pour la première fois par Murray Krieger dans la note de service (octobre 1992) de la Première Conférence Internationale sur le Discours Humaniste [Surfaces IV. 301-311 (1994)]. La première partie de cet essai tente de donner une vision d'ensemble des questions relatives à l'Humanisme et aux sciences humaines dans la Chine du XXe siècle. En recontextualisant les termes clés du Chinois, et leurs traductions culturelles, l'essai cherche à établir une base de comparaison pour situer les structures et les espaces institutionnels, à partir desquels la critique culturelle peut se développer dans la culture et la société chinoises contemporaines. Je crois que c'est seulement en localisant les différences cruciales au sein des pratiques culturelles que l'on peut élaborer une théorie comparative significative. 


\title{
Some Notes on "culture," "Humanism," and the Humanities" in Modern Chinese Cultural Discourses
}

\author{
Leo Ou-fan Lee \\ Harvard University \\ Surfaces Vol.V.207 (v.1.0A - 23/11/1995) \\ Copyright for texts published in SURFACES remains the property of authors. \\ However, any further publication should be accompanied by an \\ acknowledgement of SURFACES as the place of initial publication.
}

ISSN: $1188-2492$

\section{ABSTRACT}

This paper is written in response to the set of questions first raised by Professor Murray Krieger in the planning memo (October 1992) for the First International Conference For Humanistic Discourses [Surfaces IV. 301-311 (1994)]. The first part of this paper attempts to give a broad survey of issues related to humanism and the humanities in 20th-century China. In recontextualizing some of the key terms in Chinese and their cultural translations, the paper also seeks to lay the comparative ground for locating the institutional structures and spaces for cultural criticism in contemporary Chinese culture and society. I believe that only by locating such crucial differences in cultural practice can a meaningful comparative theory be constructed.

\section{RÉSUMÉ}

Cet essai est une réponse aux questions soulevées pour la première fois par Murray Krieger dans la note de service (octobre 1992) de la Première Conférence Internationale sur le Discours Humaniste [Surfaces IV. 301-311 (1994)]. La première partie de cet essai tente de donner une vision d'ensemble des questions relatives à l'Humanisme et aux sciences humaines dans la Chine du XXe siècle. En recontextualisant les termes clés du Chinois, et leurs traductions culturelles, l'essai cherche à établir une base de comparaison pour situer les structures et les espaces institutionnels, à partir desquels la critique culturelle peut se développer dans la culture et la société chinoises contemporaines. Je crois que c'est seulement en localisant 
les différences cruciales au sein des pratiques culturelles que l'on peut élaborer une théorie comparative significative.

Before I stake out my own positions on the subject of culture and the humanities, perhaps it might be useful to discuss briefly and in general terms some of the Chinese terms, together with their cultural histories, which may have a bearing on our discussion.*

Obvious to all native speakers of Chinese, the modern term wenhua, which may be the Chinese equivalent to culture, seems to be a commonplace. The word is made of two characters - wen and hua; each is commonly used in the classical texts, but they are seldom combined together as a word compound. When the compound does occur, it is already loaded with a "cultured" meaning: Wen, which serves to define the beginning of (elite) Chinese culture, when combined with hua, connotes that especially in its institutional form (wenzhi ) it has a kind of transformative power - in Confucian terms, that transformative influence lies in moral suasion through education (as in jiaohua). It may not be coincidental that the character wen, which originally means pattern, also forms part of the Chinese word compound for both culture and literature (wenxue ) as well as the literary arts (wenyi). These are all modern Chinese words, which were probably taken from Japanese renditions of Western terms, which in turn were borrowed from classical Chinese vocabulary. 1 Thus embedded in the very modern Chinese terminology of culture and the arts was a complex history of cultural transactions or mediations between East and West as China entered the modern world. The problem of translation lay at the very core of this historical process.

As a preliminary generalization, it can be argued that since the late 19th century the modern meaning of culture in China became intertwined with what might be called Western-oriented forms of "modernity," which in the Meiji parlance was referred to as bunmei (wenming in Chinese) or "civilization." The popular epithet for modernity was xin or "new," as in "New Culture" ( a term used in the 1920s) and "New Learning" (xinxue, a term used since the turn of the century), which became catch-phrases and referred to the trends set in motion by the "new-style" intellectuals who looked to Western knowledge as a vital source for transforming China into a modern nation. Thus, the modern word compound wenhua, a "sign" of modernity, was definitely construed as a dynamic force - so much so that it could be used later on to activate revolution. The well known phrase, "cultural revolution," popularized by Mao, could be traced back to the May Fourth movement of 1917-23, which has been seen also as a "cultural revolution" by its leaders and subsequent scholars. In this revolutionary context, culture - or more specifically New Culture - was viewed as a radical force of iconoclastic anti-traditionalism. Implicit in this formulation, some recent scholars argue, is the conviction among modern Chinese intellectuals that New Culture in the form of ideas (elitist?) has a shaping impact on personality and society. 2 Thus despite these iconoclastic ruptures 
there was at some deeper level a certain continuity with the traditional mode of thinking.

The semantic situation could be further complicated if we introduce the terms of "humanism" and "humanities." The European and Euro-centered origins of these two terms are obvious to all. It has been argued that the core of Confucianism is likewise "humanism" as it centers around the notion of ren or "humanness." $\underline{3}$ The Mencian wing of the Confucian tradition laid particular stress on this, and later thinkers, especially in one of the NeoConfucian schools of Song-Ming times, raised it to a metaphysical height. Yet it is still worth pondering the difference between these etymologies, if not the entire hermeneutic, of ren and "humanism," renxue (the study of humanity) and "humanities." Can we in fact translate the Confucian belief in ren as humanism? Since the word "humanism" has been attributed to Confucianism by 20th-century Confucian scholars, 4 this modern interpretation must itself be "historicized" as something of a metacommentary which derives its polemic power as an explicit counterstance to Chinese communism. However, since the early 1980s a number of scholars from the People's Republic have embraced Confucianism and argued for compatibility between Confucian and Marxist humanism! The present regime on the Mainland now formally espouses Confucianism as part of Chinese national heritage - that is, as part of its newly constructed "master narrative" of nationalism.

This zigzag course is nothing new. In the modern Western tradition, humanism, as Foucault reminded us, has varied greatly in content and value in different periods of European history. "And it is a fact that, at least since the seventeenth century, what is called humanism has always been obliged to lean on certain conceptions of man borrowed from religion, science, or politics. Humanism serves to color and to justify the conceptions of man to which it is, after all, to take recourse." $\underline{5}$ In the modern Chinese context, the discourse of humanism has been obliged to lean on certain Western conceptions of man by means of which it also seeks to justify itself as "modern." It may therefore be worthwhile to re-read a few familiar Chinese texts if only to clarify for our purposes the positions and connections between humanism, literature, and culture.

One of the seminal texts from the May Fourth period is Zhou Zuoren's essay on "Ren de wenxue" or "Literature of the Human Being" (1918), published in the leading intellectual journal, Xin qinian (New Youth or "La jeunesse"), which helped set the tone of the New Culture movement. What seems to me most revealing, upon re-reading this text, is not only how it declares outright its clear indebtedness to the European "discovery of the truth of human beings" 6 but its apparent leaning on a naturalist conception of science which places human beings as an animal species that becomes mankind through evolution. That the text bears the familiar Darwinian imprint is not surprising. But Zhou Zuoren then proceeds to argue, on the basis of this "scientific" stance, that "traditional literature derived from Confucian and Taoist religions is hardly qualified to be human literature," because it "obstructs the growth of human nature." 7 Thus in one blow he has destroyed the ground of the Confucian belief in the linkage between literature and culture and between culture and humanity. His new conception of "human 
nature," contrary to Confucianism, is based on a vague notion of the human individual which he calls "rendao zhuyi" - a doctrine of "humanism," if you will, in which the rendao or "human way" is left dangling, like a floating signifier, without an equivalent cultural "signified." (Sometimes the English word "humanitarianism" is used by scholars for convenience.) Although Zhou likens the human individual to a tree in a human forest, he is apparently at a loss to define the essence of the "tree" (as earlier Confucians could easily do, by resorting to ren) but seems eager to color and justify the new forest by promoting certain new values concerning human groups that he declares are not fully reflected in either Chinese and Western literatures until the end of the 19th century: he has in mind specifically the significance of women and children and, by extension, the love between the sexes which presumably is a new value highlighting the issues of feminism and sexuality as central components of Zhou's new humanism. 8 In a sense, Zhou's rambling text seems prophetically modern, even in a Western discursive context. His literary examples, drawn from the works of Ibsen, Tolstoy, Hardy, and Dostoevsky, seem to reveal a keen interest in the value of the bourgeois family's everyday life. But the "negative" examples he cites are invariably taken from traditional Chinese novels against which these Western works are foregrounded. It is clear that Zhou's new conception of humanism and human literature is not meant to trace a Western genealogy but to provide the basis of a Chinese polemic. Read in a May Fourth context, it ushers in some of the central tenets which guided the literary practice of early May Fourth writers and intellectuals, especially for the group known as the Association for Literary Studies, who used literature - particularly the genre of short stories written in the modern vernacular - to lay the groundwork of what they imagined to be a healthy human life (hence the slogan "literature for life") with a technique of "realism." Zhou's essay was written in a spirit of discovery and exploration - a text inspired by his own readings of Western literature which seeks to define the contours of a new "cultural imaginary" of Chinese modernity. His "humanism," therefore, serves not only to form a new discourse but also to open a new space in which it asserts itself as a value, however ill-defined. The term rendao zhuyi has since caught on in subsequent discussions. As such it definitely plays an active role by helping to chart a new course for May Fourth literature and culture.

A few years after the publication of Zhou's essay, a different group of intellectuals used another strand of modern Western "humanism" for a totally different purpose. The English term "humanism" was rendered by them, perhaps for the first time, as renwen zhuyi, which has since gained wide currency, though in ways that its progenitors could never have imagined. The new journal published by this group of mostly Harvardeducated students was called Xueheng or The Critical Review in their own rendition which promoted the theory of Irving Babbitt, their intellectual mentor. This episode has been known and studied by Chinese literary historians as a movement of modern Chinese conservatism, as the editors $\mathrm{Wu} \mathrm{Mi}$ and Mei Guangdi in particular - are said to have opposed May Fourth iconoclasm by using Babbitt's humanism as a defense of Chinese tradition. (Interestingly, after decades of neglect, this "conservative" group begins to receive renewed attention by younger scholars in China as they 
themselves begin to reflect upon and react against the past excessiveness of radicalism.)

The stance of the Critical Review group throws a different light on the course of modern Chinese humanism - not necessarily for its conservatism (which the group denies, preferring to call themselves "liberal") but for a different set of Western inclinations. The following is taken from "A Statement of the Critical Review" written by Wu Mi in English and published in issue No. 13 of the journal (January, 1923):

For a generation's time, China has been learning from the Western nations; and yet, it must be confessed, we are far from being acquainted with the best things and highest ideals of their civilization. We had been acquiring from the West technical knowledge, science and engineering, political machinery, educational systems and methods. It is only in the last few years that there have been notable attempts made to introduce Western literature and philosophy, etc. among our people. But the work is very unsatisfactory, because it has been done without the necessary equipment and in a wrong spirit. The men who are doing it have predilections for certain elements in Western civilization that are by no means salutary and representative, and are strongly prejudiced against all the rest in that civilization. Thus, the stories of Maupassant, the novels of the Russian authors, the plays of Ibsen and G.B. Shaw are put forth as the choice portion of European literature, to the exclusion of Dante, Shakespeare, Racine and Moliere; and no one hears the names of Plato and Aristotle, of Abelard and Aquinas, of Spinoza and Leibniz. This mode of introducing Western culture has had serious results: it has not only aggravated the Chinese people's sense of intellectual bewilderment and doubt, of spiritual unrest and pain; but it has also made the young generation as a whole innocent pretenders to knowledge, unwilling to learn, attacking everything Chinese, despising our national culture, agitating many unnecessary and even harmful changes in social life and customs, looking with scorn and contempt upon all religious and moral teaching, tending toward ignorant and bigoted and licentious individualism and away from any discipline, system and order. The proper and efficient remedy to this state of affairs, it is believed, must be the task of presenting Western civilization in its true light and total view; of giving our people the whole, and above all the best things, of Western philosophy and literature; and of spreading among the Chinese masses the true ideas and ideals which have made the West what it is. $\underline{9}$

This statement bears some scrutiny. On one level, it reads like a conventional defense of Western canons in the name of totality. Whether or not the author's disdain of Ibsen, among others, stems from Irving Babbitt (interestingly, there was no mention of Rousseau!), the stance from which this cultural critique attacks the May Fourth radicals as "pretenders to knowledge" betrays also an "arrogance behind those who would insist upon the authority of humanistic discourse." 10 For the Critical Review group, that 
authority derives from the power of academic knowledge, not to mention the new "cultural capital" they attained from an elitist Western education about a dozen years after the civil service examination - the traditional ladder of success - was abolished in 1905. In some ways, the Critical Review group, like other intellectual groups and journals, was itself an "innocent pretender to knowledge" except that their gallery of Western icons - Plato, Dante, Shakespeare, among others - was presented in a more scholarly mode, which further privileges "literature and philosophy" as presumably the basis of moral teaching. While the statement announces that the group's attitude is "neither conservative nor radical, but liberal," it is obviously a liberalism that abhors "ignorant and bigoted and licentious individualism."11 This is clearly a stance contrary to that of Zhou Zuoren's essay.

Even more revealing is the method of the Critical Review group, its "necessary equipment":

In a word, THE CRITICAL REVIEW only tries to be sound, intelligent and critical in the true sense of the word. It desires to be impartial and unpartisan; it is in full sympathy with any effort to raise the intellectual and moral standards. Lastly, THE CRITICAL REVIEW aspires to create a model style of Chinese prose, which should preserve all the good qualities of the Chinese language and should at the same be a fit vehicle for the new material of Western thought. It therefore tries to avoid pseudo-classic pedantry by rejecting all archaic words and the superfluous phrases of rhetorical ornament, and on the other hand, to follow the customary usage and idioms of the Chinese language, not to use foreign punctuation nor make all writings vulgar and unintelligible. 12

This is an astounding statement for anyone familiar with modern Chinese literary history, because it simply bypasses the central issue of the Literary Revolution, which spearheaded the May Fourth movement: the use of the modern vernacular as the language to describe and produce the New Culture. In disagreeing with the iconoclasm of the young radicals, the Critical Review "liberals" nevertheless appropriated a large dose of the radicals' language stance - that of $\mathrm{Hu}$ Shi in particular, their friend and a fellow American-educated student (Cornell and Columbia) who had, in fact, debated with them about language reform. But what is the "model style of Chinese prose" to which they aspired as a fit vehicle for introducing "new materials" of Western thought? It is but another form of classical Chinese prose, certainly not vulgar and unintelligible, but no less lacking in the use of vivid spoken idioms which Hu Shi promoted for the modern vernacular. Can this language be the proper medium to translate Plato and Shakespeare? Or is it more proper to use classical Chinese to translate Western "classics"? (In that regard, should Ibsen be translated only in the vernacular - and hence a more vulgar form of literature?) Whatever can be said about the practice of the Critical Review intellectuals, they did proceed to use their classical style to introduce and translate Irving Babbitt. A notable piece written by Wu Mi in this vein, "The Humanism of Babbitt," turns out to be a translation of an introductory article in French 
("L'Humanisme positiviste d'Irving Babbitt") by Louis J.A. Mercier and published in a French journal La revue hebdomadaire in July 1921.13 In what ways, one might ask, can Wu Mi justify the soundness and intelligence of his espousal of an American critic by translating the words of a French man (I have no idea who Mercier was), unless of course the French article was summoned to support the importance of Babbitt in the "Western" world as a whole?

A related article by Wu's friend Mei Guangdi, "Western Humanism Today," is a general introduction to the "humanism" of both Irving Babbitt and Paul E. More, described as two "established giants" of contemporary Western literary criticism.14 Mei saw these two men as thinkers who preferred literary criticism to philosophy as their profession and traced a genealogy of great thinkers who were literary critics: Voltaire, Rousseau, Goethe, Carlyle, Ruskin, Emerson, Sainte-Beuve, Renan, Taine, as well as Arnold and Pater. Mei quoted (in English) with approval Arnold's definition of the function of criticism as "a disinterested endeavor to learn and propagate the best that is known and thought in the world" and Babbitt's remark that "the chief problem of criticism, namely, the search for standard to oppose to individual caprice, is also the chief problem of contemporary thought in general: so any solution which does not go back to first principles will be worthless." 15 To Mei's mind, both literary criticism and philosophy are intended for "the study of human life," but the former is to be preferred because the latter "tends to be abstract" and uses "specialized language," whereas the former is more accessible because it uses "common language." 16 How could he imagine that the literary criticism half a century later would have become as "abstract" and "specialized" as philosophy!

It is clear that both Mei and Wu embraced a Western "humanism" of the "Great Books" - the Arnoldian notion of culture as a bastion of human values without which there can only be anarchy, which his Chinese followers equated with individual license. They also used this Western humanism to defend the relevance of Chinese classics. This is why later critics, following the May Fourth discourse, brand them as conservative. I would view it as a form of neo-classicism. With all the quotations, in which English originals closely follow their Chinese translations, accompanied by dates and explanations about the Western thinkers that are inserted in the text in small print, Mei's article reads learned indeed - very much in the typical format of classical Chinese commentary. But this classical format nevertheless contains an intrusive language which would definitely look quite exotic to the journal's readers, because most Chinese classical scholars and readers would not be able to read English. (There were a few weird exceptions, of course, such as the Edinburgh-educated Gu Hongming, who created quite a stir in Europe by promoting a kind of Chinese antiquarianism.) Moreover, this classical form and language also bespeak an elitist and scholarly sensibility that is at odds with Zhou Zuoren's essay, which is somewhat "capricious," free-wheeling, and written in an intimate vernacular. For Mei and Wu such intellectual elitism is central to a defense of "humanism" which they hold up as the standard and "first principle," albeit from the West. In Mei's essay he has attacked with considerable vehemence what he considered to be the "modern spirit to believe in creativity and freedom" - in "novelty" for its own sake which, when coupled 
with a pervasive populism, denies the importance of the privileged class of intellectuals.17 This elitist notion of humanist discourse, harking back obviously to a Chinese tradition, also reminds us of question 5 in Krieger's agenda: "Is 'elitist' discourse necessary for cultural differentiation? To expand: Does the academic humanist have the right to assign himself or herself the cultural task of definition, and to attribute value (or lack of value) to the various entities being defined?" For Mei and Wu, following Babbitt and Arnold, the answer as we all know is clearly "yes" - in fact this right forms the very foundation of being a humanist critic.

Whereas the word renwen zhuyi as a translated term may have formally entered modern Chinese discourse as a result of the vigorous promotion of the Critical Review group, it did not receive unchallenged popularity. In fact, on the literary scene of the 1930s this form of "humanism" and "liberalism" was associated by the radicals with the Anglo-American-educated intellectuals (grouped around the journal The Crescent Moon) who were opposed to revolution. At the same time, however, the May Fourth-derived discourse of human nature (renxing) and humanitarianism (rendao zhuyi) continued to hold sway among many writers, even leftists - so much so that it became a crucial part of literary practice known as social or "critical realism," the idea being that the realist technique must concern itself with explorations of the nature of human character by setting the "humanity" of fictional protagonists against the reality of the social world. On the leftist literary scene, several figures played dominant roles, in particular Lu Xun and his disciples (such Hu Feng and Feng Xuefeng). The 1930s was also a period in which a plethora of foreign literatures and literary theories were introduced, including the Soviet brand of Socialist Realism as well as works by Belinsky, Marx, Engels, and Lenin. Lu Xun - this dean of letters on the leftist front - found himself both frustrated by the confusion of revolutionary slogans and desperate to deliver some solid literary "goods" in the form of translations. So he labored long and hard to translate literary theory from Soviet Russia - Plekhanov, Lunacharsky, but also Trotsky and Lenin, and some Marx and Engels - via Japanese translations. This saga was narrated in my work on Lu Xun published some years ago, in which I tried to delineate the tragic circumstances and the intellectual limitations of this entire enterprise.18 Still, for all its confusion, the leftist legacy of the 1930s was nevertheless tinged with an ethos of "humanism" which became an target in Mao Zedong's scathing critique in his famous Talks at the Yan'an Forum on Literature and Art in 1942. The following sentences from Mao's Talks have since become prescriptive injunctions against humanism for all writers and critics in the People's Republic:

"Humanism." Is there such a thing as human nature? Of course there is. But human nature only exists in the concrete; in a class society human nature has a class character, and human nature in the abstract, going beyond class, doesn't exist. We uphold the human nature of the proletariat, while the bourgeoisie and the petty bourgeoisie uphold human nature of their own class, although they don't talk about it as such but make it out to be the only kind there is...The so-called 'humanism' which some people in Yan'an at the present time uphold as a theoretical basis for 
literature and art goes along these lines and is completely mistaken." 19

The "humanism" Mao attacked is rendao zhuyi, which is conveniently translated as "humanitarianism." This was also the prevalent term used by leftist writers in the 1930s - Mao's real target of criticism - which in turn harks back to the early May Fourth discourse of human nature. This broad ethos of rendao zhuyi may have little to do with the "humanism" (renwen zhuyi) of the American-educated "liberals," which, as discussed earlier, is close to the conservative definition of "humanities" in Western academia. Still, this "humanitarian" strain of humanism was likewise attributed by its Chinese believers to the Western tradition, albeit a different variant. $\mathrm{Hu}$ Feng, one of Lu Xun's disciples, claimed that even socialist realism can be defined "in terms of nineteenth-century humanism" because its fundamental spirit is the "concern with man...emancipation of man...and the spirit of humanism. If we turn away from this spirit, we cannot depict man realistically."20 The language used here is clearly derived from the early May Fourth discourse - for instance, that of Zhou Zuoren's essay on "Literature of Human Beings." From this assertion is derived the notion of "subjectivism" which Mao likewise attacked in Yan'an. By "classifying" humanism in the abstract as a product of the bourgeoisie, Mao not only conveniently credited himself as a Marxist theorist wielding a "class" weapon but also branded all forms of humanism (even that found in proletarian works, as it turned out) as negative. From then on, "humanism" of all hues - together with "subjectivism" and "formalism" - became taboo in Chinese Communist literary practice until Mao's death in 1976.

However, this does not mean that there have been no challenges from within: the taboo subject of humanism continued to raise its head in revolutionary discourses on literature. Aside from Hu Feng, who was finally purged together with his "gang" in the mid-1950s in a major political campaign, the most articulate voice of humanism came in 1957 from an instructor of Chinese literature in Shanghai's Eastern China Normal University. The title of Qian Gurong's text, "Wenxue shi renxue" (Literature is a Study of Human Beings) sounds like a latter-day echo of Zhou Zuoren's, and the repetition of the word "xue" brings out further the equivalence between culture (wen) and humanities; for both literature has been considered a central component. Qian's long article was produced in a climate of liberalization (the period of the "Hundred Flowers"). He quotes Mao's Talks as well as a battery of other Marxist sources to show that "humanism" (rendao zhuyi), though much abused by the capitalist class, had stemmed from 16th and 17th century Europe as an "anti-autocratic" trend. "Much as its contents had changed from time to time," Qian continues, "we can still find something in common - that is: it considers a human being a human being. In terms of the self, it means to maintain the human individual's right of autonomy and independence; in terms of others, it means mutual recognition and respect between human beings. Therefore, the so-called humanism, in a positive sense, is to obtain freedom, equality, and democracy and, in a negative sense, to oppose all unreasonable phenomena of man oppressing and exploiting man."21 In an apparent twist of Lukacsian "totality," Qian cites the familiar example of Balzac and argues that despite his own loyalist sympathies, in his fiction Balzac treats his own 
class with "pointed satire" and extends great sympathy to his enemy class. "This is because Balzac is a great humanist." 22 No wonder that Qian was silenced for the next three decades because of this single article. Yet the homeliness of these statements carries a direct force, for in his vigorous defense of humanism Qian had brought a long tradition - one that Zhou Zuoren had initiated half a century ago - to bear on the strictures of Mao's more recent canon. The term rendao zhuyi - or "humanism" in a humanitarian "way" - had somehow survived all the political campaigns and arrived at the forefront of Chinese discourse after Mao's death.

The above has been more in the nature of a survey "discourse on humanism" rather than a "humanistic discourse" proper. It does not mean, however, that the latter serves little purpose in contemporary Chinese culture and society. Rather, when we move from "humanism" to "discourse," we encounter a different set of problems. If the above survey serves little purpose for Western comparativists and theorists, at least I hope it throws some light on the question of what has been called "translatability" (Wolfgang Iser) or "untranslatability" (Jacques Derrida) - or what happens when (Western) theory travels to another cultural context? How do we bridge the gap and negotiate these different discourses? (The old model of influence studies obviously does not suffice, but would the new ones, such as Orientalism or postcolonialism, do?) I am not a theorist, nor am I willing to engage the issue "meta-theoretically." Allow me to place the discussion on a more mundane level by focusing on the differences in the institutional background of "humanism" and "culture" between modern China and contemporary America. To begin with, one institutional condition seems to be taken for granted by most American academics: that is, the academic institution itself, especially the university, as both a professional world which begets academic disciplines (of course professionalism is itself a product of rationalization in Western modernity) and an intellectual world in which culture and the humanities are defined and debated. If we put the word "academic" in question and reconsider the implications of academic elitism and arrogance in a different cultural context, such as China, we can perhaps illuminate the "functionality" or "institutionality" of culture in a different way.

In traditional China, the "academy" institution was different from traditional European models. The Buddhist church and the Confucian temple did not attain the kind of cultural supremacy attained by the Church in medieval Europe. The earliest "school" of Confucius was very personal and informal, so we gather from the Analects, not institutional. The imperial "university" was largely an honorific institution for those who obtained the highest degree on the imperial examination, often before they were assigned office. The more specific Neo-Confucian academies in Song-Ming times were not numerous; they were moreover regional and "private" institutions associated with particular Confucian thinkers. In some ways the Neo-Confucian academy sought to reproduce, at least in spirit, Confucius's own way of teaching, and it was still a far cry from educational "institutionalism" in the modern Western sense. In short, because of their limited numbers and sizes the 
traditional Chinese academies did not provide the only space for the definition and spread of culture. This is an issue which bears upon another thorny problem - the relationship between Confucianism and Chinese culture as such. The iconoclastic May Fourth intellectuals seized upon this differentiation by focusing their attack on the institution of Confucianism itself - in the metaphor of "Kongjiadian" or literally the temple or shop of the Confucian school, but for all their sound and fury, they did not destroy Chinese culture as a whole.

In spite of the fact that modern-style schools and universities replaced the traditional examination system as the dominant institution of education, it still cannot be said that they have become the sole institutions which define Chinese culture. In other words, the "elitism" of modern Chinese intellectuals was not constituted by the academy alone; rather, it was a phenomenon of a newly emergent cultural space formed by both educational institutions and the print media (journals such as the New Youth and the Critical Review and newspapers). It is in this public space of the written and printed word that modern Chinese intellectuals moved about and turned their knowledge into power. And this space in turn created its own subspaces of the elite and the popular-sometimes in the pages of the same newspaper or journal, sometimes in different journals. (For instance, the journal Dongfang zazhi or Eastern Miscellany was a publication of the Commercial Press which also published textbooks, dictionaries and popular "repositories" of new knowledge in the form of pamphlets bound together into boxes which contain translations as well as original monographs on science, philosophy, literature, politics, and others. As such the journal served the purpose of "popularization" and was criticized by some May Fourth intellectuals as too eclectic and lacking a clear intellectual stance.) The contributors to the journals and newspapers were drawn from both academic professionals (professors and teachers) and journalists and other intellectuals.

Thus, the space for cultural discourse, because it was less well defined, seems to encompass both the academic and the "popular" and definitely includes (especially in newspapers) different interest groups. This blurring of "the academic and extra-academic" institutional boundaries has some intriguing implications. For one thing, professional disciplines, especially in the area of the humanities, are ill-defined. (In the social sciences, more American-influenced disciplines, such as sociology and psychology, were pioneered by American-educated students who returned to China; of the "professional schools" medicine had an early start chiefly because of missionary influence.) As far as I can trace based on preliminary research, the first disciplinary journal based in a university with its contents centered on scholarly discourse, was started at the Southwestern United University, an institution that merged Beijing and Tsinghua universities during the war years.23 But even at this super-elitist institution, some professors were also eminent writers and critics. One such writer/professor, the poet Wen Yiduo, was assassinated by government agents because of his outspoken political views. He has been commemorated as an intellectual of social conscience although, for students of Chinese mythology, he was also an accomplished scholar. Thus it is evident that in modern China writers and intellectuals, more than professionals, had an enormous impact as role models and 
harbingers of new culture for the society at large. They gained their prestige not necessarily through institutional affiliations but through their personal behavior and above all their writing. And for all their differences, Zhou Zuoren, Wu Mi, Mei Guangdi, as well as Wen Yiduo stood in an arena of culture which cannot be simply categorized as "academic," although they all taught in the most "prestigious" universities.

When we come to the contemporary period (roughly the second half of this century), the incorporation of Western - primarily American - institutional norms and structures into the Chinese academy has itself become institutionalized. The modern university system is both entrenched and widespread. In Taiwan, the university disciplines in the humanities follow essentially the American model, whereas in Hong Kong it is a mixture of colonial British and American systems, with the latter gaining the upper hand. This means that the kind of American and English "academic culture" becomes rather familiar to intellectuals in these regions. The species of "academic intellectuals" have become a fixture in the local landscape, and they have also become increasingly fluent in the language and methodology of Western humanities: curriculum, theory, as well as their attendant politics. Theory indeed travels, at least in print and as part of an emergent bilingualism in Chinese academic culture (mainly Chinese and English, with a smattering of French and German - and occasionally Russian on Mainland China). This in turn creates a peculiar complexity concerning the issue of "Orientalism" and "post-colonialism" when it travels to that part of the world as "theory." The double-edged irony is not lost on some of the "local" intellectuals as they seek to catch up with what is going on in American academia, particularly with the works of "Third World" theorists (Said, Spivak, and others). How then should we interpret and contextualize this new phenomenon of literary reception as part of the contemporary discourse(s) of culture and the humanities? Here the "rules of the game" are much changed from the May Fourth period and become more familiar to American academics.

In spite of the increasing professionalization and academicization of intellectuals in contemporary China, the discourse of culture has not been the privileged domain of academics. Rather, academic intellectuals must go beyond the academy in order to produce cultural discourses. There are spaces "in between" academic and non-academic zones - and it is precisely in these "in-between" zones that cultural criticism is carried out. Even in places like Hong Kong and Taiwan, that space has been in the "public domain" - that is, in literary journals or daily "literary supplements" of newspapers. (In contrast, the professional "trade" journals carry prestige but little "cultural capital.") One of the consequences is that theory or metatheory does not occupy the high ground in contemporary Chinese cultural discourses - and if it does, it is not considered practice or "praxis." Rather, it seems to me that the primary "genre" of cultural criticism continues to be the essay and its variants. In Hong Kong newspapers, the regular space for such essays is the newspaper column (zhuanlan), provided for a number of authors ranging from academic intellectuals to movie stars - everyone enjoying roughly equal space! In a sense, cultural criticism becomes a kind of journalistic practice, although few reporters are known to be column writers. I have written at length about this phenomenon with 
regard to both its historical precedents and contemporary practice - in order to bring some different data to bear on Western theories of the public sphere. I did not foresee, when writing it, that the most talked about debate about the humanities in China last year took place, naturally, in a leading literary-intellectual journal called Reading (Dushu), which consists entirely of essays. The title conveys a simple pun on reading books - the journal's essays are in a nominal book review format - and the act of reading itself as general cultural practice. The journal's intellectual prestige can be illustrated by a recent refrain I have heard among university students: "You can do without reading books, but you cannot do without Reading!" But most, if not all, of the authors, including those who initiated the most recent discussion of humanism, are academics.

Thus I argue that the literary journal or "literary supplement" still occupies an important position in modern Chinese cultural discourse, which has not received much discussion in Western cultural studies, perhaps because this is regarded as a historical phenomenon no longer relevant to our "postmodern" era. In his famous book Habermas has seized upon the 18thcentury German journals of art criticism and the British "moral weeklies" of Addison and Steele together with their attendant salons and coffee houses as beginning ground for the constitution of the public sphere.24 Eagleton has dwelt on the function of criticism by invoking likewise the literary journals of 18th- and 19th-century England. Yet in neither case can we locate the modern "intellectual" as the central agent for these enterprises (in Eagleton's argument, there were men of letters or jacks-of-all-culturaltrades, but the emergence of intellectuals was a very recent phenomenon). $\underline{25}$ In the case of China, the intellectual as primary cultural voice and producer goes back to a long entrenched tradition of scholar-officials; whereas the "official" side carried on the duty of civil service, the "scholarly" side was housed in the domain of culture. The modern Chinese intellectual has inherited this tradition but has also undergone a "structural" transformation: whereas the "official" side became somewhat alienated from the state, because of the discontinuation of civil service examinations, the "scholarly" side is enhanced by both the academic and non-academic spheres of cultural activity. In Chinese, modern term "intellectual" consists of the four-character compound, "zhishi fenzi," which literally means elements or members of knowledge. The term is of recent coinage, which obviously refers to the primary significance of knowledge - in this case, new knowledge as derived from Western learning, but it also connotes a collective identity of which these self-styled individuals of new knowledge consider themselves its constituent elements. This collective identity certainly carries an elitist hallmark; however, it is not contained in academia. Rather intellectuals would prefer to place themselves in a broader and amorphous realm of public culture in which they are the leaders by virtue of their possession of new knowledge. (This is in sharp contrast to the later CCP usage of the term which refers to all who have received at least a high-school education.) It is in this public realm that they voice their political alienation and practice cultural criticism.

In view of this "intellectual" tradition, which relies among other things on the possession of "written" knowledge, and also because of the public - as opposed to academic - nature of cultural discourse, it becomes all the more 
difficult for modern Chinese intellectuals to confront the challenge of media culture, a public culture which relies on audio-visual forms of communication. The "humanism" issue raised last year by the Shanghai intellectuals was seen in some quarters as an elitist reaction against excessive commercialization and, by extension, against the domination of media culture. At the same time, however, it can also be argued that "postmodern" culture in contemporary Hong Kong and Taiwan contains a "written" element and should therefore not be considered merely a reproduction of American popular culture. In other words, the written word continues to carry some weight as cultural symbols and codes while being "mediated" and packaged into media culture. I would like to use some quotidian examples to illustrate.

Sign boards on street shops in Taiwan and Hong Kong, not to mention in China, carry a profusion of written words (as compared with visual pictures or mere signs in America). In China, moreover, most of the romanizations, presumably phonetic symbols, continue to refer to written Chinese, as if to teach the reader how to pronounce such written names or terms. In Hong Kong movie houses, superimposed dialogue subtitles, often in two "scripts" (Mandarin and Cantonese), are almost de rigueur (as opposed to American audiences who request that foreign films be dubbed in English, instead of reading subtitles). The practice of affixing a personal seal of a person's name in characters on legal documents (instead of a signature) continues to be popular in Taiwan. These numerous examples would lead us to the tentative conclusion that cultural criticism as both theory and practice would be closely connected with the written word - as a form of writing. At the same time, however, as part of the continuing saga of traveling theory, Western cultural studies is being introduced as a theory of cultural criticism, whose primary targets will have to include both print and audio-visual media, and the negotiation between the two presents some thorny problems for many intellectuals.

On a theoretical level, I am not prepared to argue at this point whether or not the Chinese equivalent to "logocentrism"26 should be formulated differently - I believe it should - simply on the basis of the relationship between writing and language (a relationship perhaps more closely interconnected in China than is found in, say, "langue" and "écriture" in France). Rather, I would venture the practical position that certain "generic" antecedents in Chinese literary culture (i.e., written culture) continue to play a role (often parodied to be sure) in contemporary visual and media culture. Again I have to use concrete examples to illustrate. Some of the generic conventions in the most popular commercial films produced in Hong Kong - such as "Peking Opera Blues," "Rouge," "Project-A," and other films by Jackie Chan, for instance - not only draw upon more recent film genres from Hollywood (e.g., cop films, the musical, etc.) and spoofs its conventions but, more significantly, hark back to similar genres in Chinese popular fiction. It is as if the filmmakers themselves sought to reestablish a connection between the (written) past and (visual) present, if only to erase or blur their obvious boundaries. Another, more immediate, reference may be found in advertisements in which even translated Western names and terms convey a literary flourish: e.g. "coca-cola" as keko kele (palatable to the mouth and joyful) and "Pepsi cola" as baishi kele (joy in everything) - 
each term naming a Western object of everyday life with a vaguely literary Chinese phrase that carries its own cultural meaning, in addition to imitating the sound of the original brand-names in English.

If the written words continue to carry Chinese meaning even when they are rendered as transliterations of the sound of Western words (as opposed to a form of Japanese transliteration in katagana in which the signs carry no apparent meaning), it spells a world of difference from a culture governed largely by phonetic language systems. If, as everyone knows, the nature and evolution of the Chinese language is both ideographic and phonetic (but not alphabetic), the implications for contemporary culture must also be significant. The discourse of culture, therefore, must also take a different turn.

Here the problems become even more complex because of the usage of the word "discourse" (translated in Mainland China as huayu which is clearly Western. Leaving aside its French origin (discours) we can perhaps say that "discourse" presupposes at the most basic level the differentiation of two separate things - the thing itself and the language with which the thing can be named or talked about. In both its original Western meaning and its Chinese translation, the term privileges the language side of the balance. But what is the function of language vis-à-vis the "reality" it seeks to talk about? In traditional Chinese culture, as far as I know, the two only seem to occupy two different semantic spaces (e.g., "the tao that can be talked about is not the everlasting tao"), but their mutual interaction may have been more "organic" - that is, language does not necessarily take priority over "reality." (I realize I am treading on very dangerous ground here.) On this basis, we should perhaps reconsider the relationsip between text, author, and reader in the context of traditional and modern Chinese culture. In classical Chinese literary criticism, the author is not dead but figures significantly in the fabric of a cultural landscape which is also woven intertextually. Thus the notion of wen ru qi ren - the writing (style) resembles the person (author) - should not be dismissed lightly. For it refers to a relationship somewhat comparable to that between language and reality. Accordingly, both author and text occupy and participate in the same cultural space, and wen ru qi ren in this instance refers to a chain of cultural mediations which covers the entire spectrum from the "literary language" within a text all the way to the real-life author.

This is of course a loaded subject which I cannot fully amplify here. In modern China since the May Fourth period, the author has both a social and artistic persona; as the former s/he enjoyed an exalted position as an intellectual par excellence; as the latter s/he is a creator of literary texts in which s/he is often present. The famous writer Ba Jin went so far as to claim that there is no distance whatsoever between him as author (in or outside his novels) and his (real, not imagined) readers. In this regard, even literary modernism in China should not be considered merely as a new mode of language or a reflection of the new condition of bourgeois individualism under high capitalism but (especially in post-Mao China) rather as a public cultural practice which carries a political, and often subversive, meaning. In fact, perhaps nowhere in the postmodern world can one encounter, as in the China of the mid-1980s, a large-scale movement known as "cultural fever" 
(wenhuare) waged by dissatisfied intellectuals who used the trope of modern culture as a weapon to oppose government ideology.

I have provided all this "background information"in the hope that it can be theorized in a more international framework of "multiculturalism." In this regard, the task of a humanist is indeed one of "culture and cultures." For Western academic humanists, the "spaces between"can be theorized into existence. For humanists in China and elsewhere, they have to be opened up not only by theory but by concrete cultural practice-sometimes even by dedicated "struggle."

\section{NOTES}

* Paper written for the Irvine conference on "Culture and Cultures: and the Spaces Between," March 31-April 5, 1995.

1 See the appendix section (of modern Chinese terms retranslated from the Japanese) in Lydia Liu's forthcoming book, Translingual Practice (Stanford: Stanford Univ. Press, 1995).

2 Yu-sheng Lin, The Crisis of Chinese Consciousness: Radical Antitraditionalism in the May Fourth Era (Madison, Wis.: Univ. of Wisconsin Press, 1979).

$\underline{3}$ I have intentionally bypassed a discussion of Confucianism as this has been done already by Professor Wei-ming Tu in his many writings.

$\underline{4}$ The modern originator of this argument is Prof. Tang Junyi of New Asia College, Hong Kong. See, for instance, his Zhongguo renwen jingshen zhi fazhan (The Development of the Humanistic Spirit in China), in Tang Junyi quanji (The Complete Works of Tang Junyi) (Taipei: Xuesheng shuju,),vol. 6.

$\underline{5}$ Michel Foucault, "What Is Enlightenment?" in Paul Rabinow, ed., The Foucault Reader (New York: Pantheon Books, 1984), p. 44.

$\underline{6}$ Zhou Zuoren, "Ren de wenxue," in Yang Mu (C.H. Wang), ed., Zhou Zuoren wenxuan (Selected Essays of Zhou Zuoren); (Taipei: Hongfan shudian, 1983),vol. 1, p. 64.

7 Ibid., pp. 68-69.

8 Ibid., pp. 64, 69-70.

9 Xueheng No. 13 (Jan., 1923), pp. 1-2.

10 Murray Krieger, Initial definition and planning memo (October 1992) for this conference, "Culture and Cultures: and the Spaces Between" (Surfaces, IV. 301).

11 Ibid., p. 2.

12 Ibid., p. 3. 
13 Wu Mi, "Bai Bide zhi renwen zhuyi," Xueheng, No. 19 (July, 1923), p. 1.

14 Mei Guangdi, "Xianjin xifang renwen zhuyi," Xueheng No. 8 (1922), p. 3.

15 Ibid., pp. 4-5.

$\underline{16}$ Ibid., p. 6.

17 Ibid., p. 1.

18 Leo Ou-fan Lee, Voices from the Iron House: A Study of Lu Xun

(Bloomington: Indiana Univ. Press, 1987), chap. 8.

19 See Bonnie S. McDougall, Mao Zedong's "Talks at the Yan'an Conference on Literature and Art": A Translation of the 1943 Text with Commentary (Ann Arbor, Michigan: Center for Chinese Studies, Univ. of Michigan, 1980), p. 79 .

20 Merle Goldman, Literary Dissent in Communist China (Cambridge, Ma.: Harvard Univ. Press, 1967), p. 141.

21 Qian Gurong, Lun "wenxue shi renxue" (On "Literature Is the Study of Man") (Beijing: Renmin wenxue chubanshe, 1981), pp. 27-28.

$\underline{22}$ Ibid., p. 20.

23 The journal (1942-53) is called "Renwen kexue xuebao" or "Learned Journal of the Humanistic Sciences." I am grateful to my student and research assistant Chen Jianhua for his research help.

24 Jurgen Habermas, The Structural Transformation of the Public Sphere (Cambridge, Ma.: MIT Press, 1991), pp. 40-42.

25 Terry Eagleton, The Function of Criticism: from The Spectator to PostStructuralism (New York: Verso, 4th printing, 1990), pp. 45-47.

26 For a brilliant treatise on this subject see Longxi Zhang, The Tao and the Logos (Durham, N.C.: Duke Univ. Press, 1993). My views on this may differ slightly from Zhang's. 